\title{
Stomatologiczne przygotowanie pacjenta do zabiegu transplantacji macierzystych komórek krwiotwórczych (HCT) na podstawie piśmiennictwa i doświadczeń własnych
}

\author{
Dental preparation of the patient \\ undergoing hematopoietic stem cell transplantation (HCT) \\ based on literature and own experience
}

\footnotetext{
1 Zakład Stomatologii Zintegrowanej, Katedra Stomatologii Zachowawczej, Warszawski Uniwersytet Medyczny

${ }^{2}$ Instytut Hematologii i Transfuzjologii, Klinika Transplantacji Komórek Krwiotwórczych, Warszawa
}

DOI: http://dx.doi.org/10.20883/df.2018.25

\begin{abstract}
STRESZCZENIE
Przeszczepienie komórek krwiotwórczych (HCT — ang. Hematopoietic Cell Transplantation) wiąże się z wysokim ryzykiem powikłań w jamie ustnej, które znacząco obniżają jakość życia pacjenta, a w niektórych przypadkach zagrażają jego zdrowiu i życiu. Właściwa opieka stomatologiczna odgrywa kluczową rolę w obniżeniu tego ryzyka. W artykule omówiono przygotowanie stomatologiczne chorego do zabiegu transplantacji macierzystych komórek krwiotwórczych (HCT) na podstawie piśmiennictwa i doświadczeń własnych, ze szczególnym uwzględnieniem zasad podstawowej opieki stomatologicznej (BOC — ang. Basic Oral Care), rozumianej jako systematyczne przeprowadzanie rutynowych czynności mających na celu podtrzymywanie zdrowia jamy ustnej i zapobieganie powikłaniom. Omówiono przygotowanie stomatologiczne chorego do przeszczepienia, z podkreśleniem konieczności eliminacji potencjalnych ognisk zakażenia i źródeł krwawienia.
\end{abstract}

Słowa kluczowe: przeszczepienie komórek krwiotwórczych, opieka stomatologiczna, okres przed przeszczepieniem.

\begin{abstract}
Hematopoietic cell transplantation (HCT) still carries a high risk of side effects that frequently occur in the oral cavity and often significantly decrease the patients' quality of life. Therefore, it is mandatory that all patients referred to HCT undergo thorough dental examination and receive appropriate treatment before the procedure. This paper presents a review of dental management methods intended for patients before HCT proposed in the literature as well as recommendations based on the experience of authors of the publication, with particular emphasis on the principles of basic dental care (BOC - Basic Oral Care), understood as systematic carrying out of routine procedures aimed at maintaining oral health and preventing complications. The article pays special attention to the problem of potential foci of infection and bleeding.
\end{abstract}

Keywords: hematopoietic cell transplantation, dental care, pre-transplant period.

Dzięki stałemu i dynamicznemu rozwojowi nauk medycznych coraz powszechniej stosuje się leczenie za pomocą przeszczepiania narządów i tkanek. Do najczęściej przeprowadzanych zabiegów tego rodzaju należy obecnie transplantacja macierzystych komórek krwiotwórczych (HCT - ang. Hematopoietic Cell Transplantation) [1]. Jest to metoda stosowana w leczeniu osób dotkniętych nowotworowymi i nienowotworowymi chorobami układu krwiotwórczego oraz w terapii niektórych guzów litych [2].
W zależności od źródła, z którego pochodzą komórki macierzyste, możemy mieć do czynienia z przeszczepieniem allogenicznym lub autologicznym. W zabiegu przeszczepienia allogenicznego (alloHCT - ang. allogeneic Hematopoietic Cell Transplantation) transplantowany materiał pochodzi od dawcy rodzinnego bądź niespokrewnionego. Natomiast przeszczepienie autologiczne (autoHCT - ang. autologic Hematopoietic Cell Transplantation), w ogólnym zarysie, polega na podaniu choremu jego własnych komórek krwio- 
twórczych [2]. Według raportu European Society for Blood and Marrow Transplantation, w 2013 r., w Europie przeprowadzono przeszczepienia u 34 809 pacjentów (transplantacje pierwszorazowe), w tym u 19859 osób (57\%) dokonano autotransplantacji, a u 14950 (43\%) allotransplantacji [3]. W Polsce w 2013 wykonano 847 autotransplantacji i 493 allotransplantacje, w 18 ośrodkach przeszczepowych [1]. Stale rośnie liczba pacjentów o długim okresie przeżycia po zabiegu [4].

Mimo postępów w terapii, HCT nadal wiąże się z dużym ryzykiem powikłań oraz z wysoką śmiertelnością [2]. Powikłania te występują również w jamie ustnej [5, 6], dotykając około $80 \%$ chorych [7]. Są one przede wszystkim skutkiem choroby zasadniczej i/lub jej leczenia. Mielosupresja i immunosupresja prowadzą do neutropenii, trombocytopenii i anemii, które manifestują się $w$ jamie ustnej nawracającymi infekcjami, częstymi krwawieniami oraz objawami typowymi dla niedokrwistości [8]. Jednak, jak wynika z piśmiennictwa, również nieprawidłowe przygotowanie stomatologiczne do transplantacji oraz niewłaściwa pielęgnacja jamy ustnej w okresie pozabiegowym istotnie zwiększają ryzyko powikłań miejscowych, a niekiedy ogólnoustrojowych [9-13]. Niestety, tylko część chorych zostaje poddanych specjalistycznemu badaniu stomatologicznemu na etapie przygotowania do przeszczepienia [10, 14]. Według obserwacji Barkera odsetek ten wynosi około $40 \%$ pacjentów [15]. Problemem jest także brak algorytmów postępowania stomatologicznego, opartych na wiarygodnych badaniach klinicznych, przeznaczonych dla dorosłych osób poddawanych przeszczepieniu [5, 10, 16, 17]. Dostępne schematy, bazujące na praktyce własnej ośrodków przeszczepowych, są niekiedy sprzeczne i mało precyzyjne. Przykładowo, w literaturze proponuje się aż 80 różnych leków i ich kombinacji dla złagodzenia dolegliwości występujących w jamie ustnej [18].

Poniższy artykuł przedstawia przegląd sugerowanych $w$ piśmiennictwie zasad opieki nad pacjentami przygotowywanymi do zabiegu HCT, a także zasad wynikających z doświadczeń własnych. Według wskazań Multinational Association of Supportive Care in Cancer/International Society of Oral Oncology (MASCC/ISOO) oraz the European Society for Blood and Marrow Transplantation (EBMT), na każdym etapie procedury przeszczepowej należy w pierwszej kolejności realizować zasady podstawowej opieki stomatologicznej (BOC — ang. Basic Oral Care), rozumianej jako systematyczne przeprowadzanie pacjenta i/lub opiekunów rutynowych przez czynności mające na celu podtrzymywanie zdrowia jamy ustnej i zapobieganie powikłaniom. Do czynności tych zaliczono: zapobieganie infekcjom, kontrolę bólu, podtrzymywanie funkcji jamy ustnej (spożywanie pokarmów, mowa), leczenie i łagodzenie objawów powikłań terapii podstawowej, poprawę jakości życia pacjentów [8].

\section{Przygotowanie jamy ustnej}

Procedura transplantacji komórek krwiotwórczych obejmuje leczenie przygotowawcze (kondycjonowanie), zabieg przeszczepienia oraz terapię po transplantacji [19]. W ramach kondycjonowania chorego poddaje się terapii niszczącej komórki układu odpornościowego, w celu uniknięcia odrzucenia przeszczepu. Równocześnie w szpiku powstaje wolna przestrzeń dla komórek krwiotwórczych dawcy oraz niszczone są pozostałe komórki nowotworowe. Przygotowanie immunosupresyjne wymaga podawania wysokich dawek leków antyproliferacyjnych, w niektórych przypadkach połączonego $\mathrm{z}$ frakcjonowanym napromienianiem całego ciała (TBI - ang. Total Body Irradiation).

Właściwą procedurę transplantacyjną poprzedza postępowanie ogólnomedyczne polegające m.in. na leczeniu przedprzeszczepowym biorcy [19]. Już na tym etapie należy objąć pacjenta także ścisłą, specjalistyczną opieką dentystyczną, a doświadczony stomatolog powinien zostać włączony do zespołu transplantacyjnego [20]. Sanacja jamy ustnej musi zostać wdrożona i zakończona najszybciej jak to tylko możliwe przed rozpoczęciem kondycjonowania [5]. Polega ona przede wszystkim na wykryciu oraz wyeliminowaniu aktywnych i potencjalnych źródeł infekcji w układzie stomatognatycznym, a także na usunięciu czynników miejscowych mogących stanowić przyczynę krwawienia (Tabela 1).

Zaleca się, aby przygotowanie stomatologiczne do transplantacji obejmowało następujące etapy:

1) badanie pacjenta,

2) ustalenie planu leczenia $w$ ścisłym porozumieniu z lekarzem hematologiem,

3) przeprowadzanie zabiegów leczniczych stomatologicznych,

4) przeprowadzenie instruktażu higieny jamy ustnej,

5) włączenie płukanek antybakteryjnych,

6) wdrożenie profilaktyki fluorowej.

\section{Badanie pacjenta}

Badanie podmiotowe obejmuje wywiad stomatologiczny oraz ogólnomedyczny, w którym należy zwrócić szczególną uwagę na informacje dotyczące: > choroby podstawowej, będącej wskazaniem do $\mathrm{HCT}$, 
Tabela 1. Potencjalne ogniska zakażenia i czynniki miejscowe mogące wywołać krwawienie [15, 21, 22]

Table 1. Potential infection sites and local factors able to cause bleeding [15, 21, 22]

\begin{tabular}{|l|l|}
\hline \multicolumn{1}{|c|}{ Ogniska zakażenia } & \multicolumn{1}{|c|}{ Czynniki wywołujące krwawienie } \\
\hline - Kieszenie przyzębne > $6 \mathrm{~mm}$ & - Złamane zęby, wypełnienia \\
- Zapalenie przyzębia z objęciem furkacji & - Ostre krawędzie zębów, wypełnień \\
- Zęby z próchnicą głęboką & - Źle przylegające protezy \\
- Zęby z rozległymi wypełnieniami & - Aparaty ortodontyczne \\
- Zęby z miazgą martwą, w stanie rozpadu zgorzelinowego lub objętą stanem & - Zęby kontaktujące się bezpośrednio \\
& zapalnym \\
- Zęby z ostrym lub przewlekłym zapaluzową strony przeciwstawnej \\
- Utrudnione wyrzynanie zęba, z towarzyszącymi objawami patologicznymi \\
- Kamień nad i poddziąsłowy
\end{tabular}

> planowanej daty transplantacji,

$>$ typu dawcy,

źródła komórek krwiotwórczych: szpik kostny, komórki obwodowe, krew pępowinowa,

, planowanego kondycjonowania: z zastosowaniem chemioterapii czy chemio- radioterapii,

, aktualnego statusu hematologicznego i immunologicznego pacjenta,

, chorób towarzyszących,

przyjmowanych leków,

założonych wkłuć stałych [23].

Badanie przedmiotowe przeprowadza się według ogólnie przyjętych zasad. Konieczne jest wykonanie zdjęcia pantomograficznego szczęki i żuchwy oraz zależnie od potrzeb zdjęć wewnątrzustnych [24, 25]. Wynik badania zostaje następnie przekazany lekarzowi hematologowi. W pisemnej informacji należy zwrócić szczególną uwagę na zmiany patologiczne wymagające interwencji przed przeszczepieniem, w tym zwłaszcza na:

, zęby, które muszą być leczone z powodu próchnicy, zwłaszcza próchnicy głębokiej,

> zęby wymagające leczenia endodontycznego,

> zęby wymagające ekstrakcji,

> choroby przyzębia,

zmiany na błonie śluzowej.

Warto również określić optymalny czas, jaki byłby potrzebny na realizację niezbędnych procedur stomatologicznych.

Jak stwierdzono w badaniach Durey i wsp. ponad $90 \%$ pacjentów przygotowywanych do HCT wymaga leczenia stomatologicznego przed zabiegiem przeszczepienia. Do problemów najczęściej występujących w tym okresie należą: grzybica błony śluzowej jamy ustnej, zapalenie przyzębia z towarzyszącym krwawieniem, próchnica zębów oraz zapalenie tkanek okołowierzchołkowych zębów. Ponadto pacjenci często uskarżają się na suchość jamy ustnej. Obserwowane zmiany patologiczne mogą być skutkiem choroby podstawowej i jej le- czenia, a także zaniedbań higieny wynikających z niskiej świadomości oraz motywacji osób dotkniętych poważnymi schorzeniami ogólnoustrojowymi [26].

\section{Ustalenie planu leczenia}

Przeprowadzenie pełnej sanacji jamy ustnej przed wdrożeniem postępowania przeszczepowego nie zawsze jest możliwe. Może to wynikać z braku odpowiedniej ilości czasu, jaką dysponuje stomatolog do momentu rozpoczęcia kondycjonowania. Często przeszkodę stanowi także zły stan ogólny chorego, a zwłaszcza parametry krwi niepozwalające na wykonanie zabiegów inwazyjnych. Trzeba brać również pod uwagę możliwości finansowe pacjenta oraz dostępność opieki dentystycznej. Ponadto bardzo ważna jest motywacja dotycząca terapii stomatologicznej oraz pielęgnacji jamy ustnej. Leczenie zachowawcze zębów można przeprowadzać tylko przy dobrej współpracy osoby przygotowywanej do przeszczepienia. W przeciwnym razie powinno się rozważyć usunięcie wszystkich zębów, których rokowanie jest wątpliwe [8, 23].

Należy podkreślić, że stomatolog jest zobowiązany do ścisłej współpracy z hematologiem na wszystkich etapach terapii przeszczepowej. Szczególnie odnosi się to do planowania czynności inwazyjnych, takich jak np. ekstrakcja zęba. Przed przeprowadzeniem tego rodzaju zabiegów trzeba wziąć pod uwagę ryzyko bakteriemii związane z procedurą. W razie wątpliwości zaleca się skonsultowanie wskazań do osłonowej antybiotykoterapii z lekarzem prowadzącym. Będą jej wymagali przede wszystkim pacjenci, u których liczba granulocytów we krwi obwodowej wynosi $\leq 2000 / \mathrm{mm}^{3}$ $[27,28]$. O ile hematolog nie zdecyduje inaczej, postępuje się wg zaleceń opracowanych przez American Heart Association [23] (Tabela 2).

Ryzyko przedłużonego krwawienia, wynikające z choroby podstawowej, jej leczenia i/lub z cho- 
Tabela 2. Zalecana osłonowa antybiotykoterapia przy zabiegach stomatologicznych (wg American Heart Association 2007) $[23,29]$

Table 2. Recommended preventive antibiotic therapy in dental treatment (according to American Heart Association 2007) [23, 29]

\begin{tabular}{|l|c|c|}
\hline \multicolumn{1}{|c|}{ Sytuacja kliniczna } & Lek & Dawka \\
\hline Podawanie doustne & Amoksycylina & $2 \mathrm{~g}$ \\
\hline Alergia na penicyliny & $\begin{array}{c}\text { Klindamycyna } \\
\text { LUB }\end{array}$ & $600 \mathrm{mg}$ \\
& $\begin{array}{c}\text { Cefalosporyny (np. Cefaleksyna) } \\
\text { LUB }\end{array}$ & $2 \mathrm{~g}$ \\
\hline Niemożność doustnego przyjmowania leków & Aakrolidy (azytromycyna: Sumamed, klarytromycyna: Klacid) & $500 \mathrm{mg}$ \\
\hline $\begin{array}{l}\text { Niemożność doustnego przyjmowania leków } \\
\text { i alergia na penicyliny }\end{array}$ & LUB & $2 \mathrm{~g}$ im lub iv \\
& Cefalosporyny (cefazolina) & $1 \mathrm{~g}$ im lub iv \\
\hline
\end{tabular}

rób towarzyszących, może utrudniać wprowadzenie planowanego leczenia. Należy wówczas ustalić $z$ hematologiem termin i warunki przeprowadzenia zabiegu. U niektórych pacjentów procedury inwazyjne będą musiały odbywać się w warunkach szpitalnych. Transfuzja płytek krwi zwykle jest wymagana, jeżeli ich liczba utrzymuje się na poziomie $\leq 30000 / \mathrm{mm}^{3}[24,27]$. $U$ chorych przygotowywanych do HCT istnieje również ryzyko wystąpienia powikłań wynikających z terapii choroby podstawowej i/lub chorób towarzyszących. Trzeba pamiętać, że niektóre leki stosowane w terapii stomatologicznej mogą nasilać krwawienie (np. ibuprofen, kwas acetylosalicylowy) [30]. Z kolei inne wchodzą w interakcje ze środkami i lekami stosowanymi w postępowaniu stomatologicznym np. flukonazol nasila toksyczne działanie niesteroidowych leków przeciwzapalnych, cyklosporyny, cyklofosfamidu, kortykosterydów oraz niektórych leków nasercowych (werapamil, nifedypina) [30].

\section{Przeprowadzanie zabiegów stomatologicznych}

Istotne jest, aby czynności lecznicze wdrożyć najszybciej, jak tylko jest to możliwe. Procedury inwazyjne (np. ekstrakcja zęba, skaling) powinny zostać przeprowadzone najpóźniej na 10 dni przed przewidywanym spadkiem poziomu granulocytów poniżej 500/mm $\mathrm{mm}^{3}$ [28]. Jak wspomniano wcześniej, $w$ literaturze brak jest ogólnie przyjętego algorytmu dotyczącego zasad przygotowania dorosłego pacjenta do HCT. Opinie autorów różnią się zwłaszcza w podejściu do określenia tych potencjalnych ognisk zakażenia w układzie stomatognatycznym, które muszą zostać bezwzględnie wyeliminowane przed rozpoczęciem chemio/radioterapii kondycjonującej. Niektórzy zdecydowanie opowiadają się za restrykcyjną sanacją jamy ustnej, zalecając usunięcie każdego potencjalnego źródła infekcji [31, 32]. Ich zdaniem warunek ten powinien zostać spełniony, niekiedy nawet kosztem przesunięcia zabiegu transplantacji. Zwracają uwagę na fakt, że jama ustna stanowi wrota dla zakażeń układowych w okresie neutropenii $[4,9,11,33]$, a usunięcie wszystkich aktywnych i potencjalnych ognisk infekcji może istotnie obniżać ryzyko powikłań miejscowych i ogólnoustrojowych, związanych z immunosupresją (od $40 \%$ do 12\%) [31, 35]. Z kolei inni autorzy dopuszczają ograniczone, minimalnie inwazyjne postępowanie stomatologiczne przed zabiegiem HCT [26, 36-38]. Wskazują oni na niekorzystne aspekty rygorystycznego podejścia do usuwania potencjalnych ognisk zakażenia, w tym m.in. na konieczność zmiany planu leczenia choroby podstawowej. Podkreśla się, że zabieg inwazyjny sam w sobie niesie ryzyko infekcji i zwiększa niebezpieczeństwo przedłużonego krwawienia $[38,39]$. Ponadto, przy założeniach restrykcyjnej sanacji niejednokrotnie usuwa się zęby w innych warunkach kwalifikujące się do leczenia, okaleczając $w$ ten sposób pacjenta $[3,37]$. Braki zębowe mogą przyczyniać się m.in. do zaburzeń w odżywianiu, szczególnie że użytkowanie uzupełnień protetycznych po przeszczepieniu często jest utrudnione. Według Yamagata i wsp. przed HCT należy usunąć wszystkie potencjalne ogniska zakażenia, o ile pozwala na to plan leczenia hematologicznego, przy czym autorzy zalecają ekstrakcje zębów jedy- 
Tabela 3. Proponowany protokół minimalnie inwazyjnego postępowania stomatologicznego u pacjenta przygotowywanego do transplantacji macierzystych komórek krwiotwórczych [5, 22, 24, 31, 36, 38, 40, 41]

Table 3. Recommended protocol for minimally invasive dental procedures in patients prepared for alloHCT [5, 22, 24, 31, 36, $38,40,41]$

\begin{tabular}{|c|c|c|}
\hline \multirow{2}{*}{ 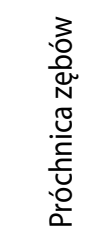 } & Powierzchowna i średnia & $\begin{array}{l}\text { - Założenie wypełnienia stałego } \\
\text { - Założenie wypełnienia czasowego, glasjonomerowego } \\
\text { - Odroczenie leczenia na okres po hct }\end{array}$ \\
\hline & Głęboka & $\begin{array}{l}\text { - Leczenie zachowawcze z założeniem wypełnienia stałego } \\
\text { - Leczenie zachowawcze z założeniem wypełnienia czasowego } \\
\text { - Pulpectomia }\end{array}$ \\
\hline \multirow{4}{*}{ 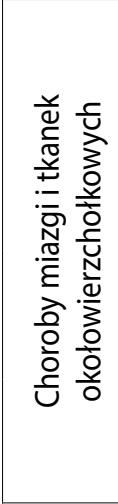 } & Zapalenie miazgi & $\begin{array}{l}\text { - Pełne leczenie endodontyczne, z ostatecznym wypełnieniem kanałów } \\
\text { - Wstępne biomechaniczne opracowanie kanałów z czasowym wypełnieniem }\end{array}$ \\
\hline & $\begin{array}{l}\text { Martwica/zgorzel miazgi bez } \\
\text { objawów zapalenia około- } \\
\text { wierzchołkowego }\end{array}$ & $\begin{array}{l}\text { - Pełne leczenie endodontyczne, z ostatecznym wypełnieniem kanałów } \\
\text { - Wstępne biomechaniczne opracowanie kanałów z czasowym wypełnieniem } \\
\text { - Leczenia endodontycznego nie można podejmować jeżeli osiągnięcie mielosupresji } \\
\text { spodziewane jest w ciągu najbliższych } 7 \text { dni }\end{array}$ \\
\hline & $\begin{array}{l}\text { Przewlekłe zapalenie tkanek } \\
\text { okołowierzchołkowych }\end{array}$ & $\begin{array}{l}\text { - Pełne leczenie endodontyczne } \\
\text { - Wstępne biomechaniczne opracowanie kanałów z czasowym wypełnieniem } \\
\text { - Ekstrakcja }\end{array}$ \\
\hline & $\begin{array}{l}\text { Ostre/ przewlekłe, zaostrzone } \\
\text { zapalenie tkanek okołowierz- } \\
\text { chołkowych }\end{array}$ & $\begin{array}{l}\text { - Pełne leczenie endodontyczne } \\
\text { - Wstępne biomechaniczne opracowanie kanałów z czasowym wypełnieniem } \\
\text { - Ekstrakcja }\end{array}$ \\
\hline \multicolumn{2}{|c|}{ Choroby przyzębia } & $\begin{array}{l}\text { - Usunięcie złogów nazębnych i wygładzenie ostrych brzegów wypełnień, uzupełnień } \\
\text { protetycznych, zębów } \\
\text { - Usunięcie zębów: z kieszeniami głębszymi niż 5-6 mm, dotkniętych zespołem endo- } \\
\text { periodontalnym, z zajeciem furkacji ii i iii stopnia, znacznie rozchwianych (ruchomość } \\
\text { iii stopnia) } \\
\text { - Usunięcie implantów z kieszeniami głębszymi niż 5-6 mm }\end{array}$ \\
\hline \multicolumn{2}{|c|}{ Zęby zatrzymane } & $\begin{array}{l}\text { - Usunięcie zębów częściowo lub całkowicie wyrzniętych, z objawami ostrego albo } \\
\text { przewlekłego stanu zapalnego }\end{array}$ \\
\hline \multicolumn{2}{|c|}{ Leczenie ortodontyczne } & $\begin{array}{l}\text { - Usunięcie stałych aparatów ortodontycznych } \\
\text { - Ponownie leczenie ortodontyczne można wdrożyć po roku od hct, o ile pacjent nie } \\
\text { przyjmuje leków immunosupresyjnych }\end{array}$ \\
\hline \multicolumn{2}{|c|}{ Leczenie protetyczne } & $\begin{array}{l}\text { - Usunięcie wadliwych, stałych uzupełnień protetycznych } \\
\text { - Ruchome uzupełnienia protetyczne mogą być użytkowane w zależności od stanu } \\
\text { błony śluzowej (mucositis, suchość) oraz stanu protezy (stare, akrylowe uzupełnienia } \\
\text { stanowią rezerwuar patogenów) }\end{array}$ \\
\hline \multicolumn{2}{|c|}{ Inne zabiegi i zalecenia } & $\begin{array}{l}\text { - Korekta kształtu lub usunięcie zębów wynicowanych, kontaktujących się z błoną } \\
\text { śluzową strony przeciwstawnej. Leczenie parafunkcji }\end{array}$ \\
\hline
\end{tabular}

nie w ograniczonych przypadkach [38]. W tabeli 3 przedstawiono proponowane zasady minimalnie inwazyjnego postępowania stomatologicznego.

\section{Instruktaż pielęgnacji jamy ustnej}

Stanowi niezwykle ważny i niedoceniany element przygotowania pacjenta do transplantacji. Przed rozpoczęciem terapii onkologicznej niezbędne jest przedstawienie choremu negatywnych skutków terapii, których objawy mogą być widoczne $w$ jamie ustnej oraz sposobów zapobiegania im i leczenia. Niestety, jak wynika $z$ literatury, w fazie poprzedzającej HCT tylko około 30\% biorców otrzymuje informacje tego rodzaju [7, 42].
Zasady pielęgnacji jamy ustnej muszą być zawsze dostosowane do indywidualnych potrzeb chorego. Należy je przekazać nie tylko pacjentowi, ale również osobom opiekującym się chorym (rodzina, personel medyczny). Instruktaż powinien mieć formę ustną i pisemną oraz zawierać informacje dotyczące:

, oczyszczania zębów, w tym rodzaju pasty, szczotki, dodatkowych przyrządów np. nici, irygatorów,

, pielęgnacji błony śluzowej jamy ustnej, w tym zwłaszcza środków do płukania jamy ustnej,

, metod fluoryzacji,

, pielęgnacji uzupełnień protetycznych. 


\section{Szczotka, pasta do zębów}

Oczyszczanie zębów powinno się odbywać co najmniej dwa razy dziennie, po każdym jedzeniu jeśli to możliwe. Szczotka do zębów miękka lub średniomiękka, manualna lub elektryczna, wymieniana raz w miesiącu. Zalecane są pasty do zębów nie zawierające laurylosiarczanu sodowego, który może drażnić błonę śluzową (np. Elmex, Curaprox enzycal, Sensodyne). Jeśli pacjent nie ma problemów z krwawieniem z dziąseł może stosować dodatkowe instrumenty do utrzymywania higieny jamy ustnej, jak nici dentystyczne, wykałaczki czy irygator.

Oprócz przeprowadzenia instruktażu higieny trzeba również zmotywować pacjenta oraz jego opiekunów do utrzymywania właściwego reżimu dietetyczno-higienicznego. Choremu należy zwrócić szczególną uwagę na konieczność częstej kontroli stomatologicznej.

\section{Płukanki antybakteryjne}

Ze względu na podwyższone ryzyko rozwoju infekcji w jamie ustnej (szczególnie wysokie we wczesnym okresie potransplantacyjnym) wskazane jest wprowadzenie dodatkowych, miejscowych preparatów antybakteryjnych w postaci płukanek. Środki te pacjent włącza na 7-14 dni przed rozpoczęciem kondycjonowania. Zalecane są przede wszystkim bezalkoholowe płukanki zawierające chlorheksydynę (np. Alfamed, Curasept). Zaleca się płukanie jamy ustnej wodnym roztworem chlorheksydyny: $10 \mathrm{ml}$ roztworu $0,2 \%$ lub $18 \mathrm{ml}$ roztworu $0,12 \%$, 2 razy dziennie. Można rozcieńczać z wodą w proporcji 1:1. Nie jeść, nie szczotkować zębów przez godzinę po płukaniu. Nie używać bezpośrednio po myciu zębów pastą (godzina przerwy). Nie łączyć z preparatami przeciwgrzybiczymi do pędzlowania błony śluzowej, zwłaszcza z nystatyną (co najmniej godzina przerwy). Płukanki włączyć najpóźniej na 7 dni przed rozpoczęciem chemio/radioterapii [23].

\section{Wdrożenie profilaktyki fluorowej}

Pacjenci poddawani HCT znajdują się w grupie podwyższonego ryzyka rozwoju próchnicy. Ma to związek przede wszystkim z niedoborem wydzielania śliny, który dotyka ponad połowę chorych w okresie potransplantacyjnym [43, 44]. Ponadto zapalenie błony śluzowej będące m.in. efektem stosowanej chemio/radioterapii oraz stan ogólny pacjenta często uniemożliwiają dokładne oczyszczanie jamy ustnej. Dlatego też zaleca się wprowadzenie dodatkowych metod remineralizacji, jeszcze przed rozpoczęciem właściwej procedu- ry przeszczepowej. Profilaktykę fluorową $w$ tym okresie stosuje się według ogólnie przyjętych zasad dla grupy wysokiego ryzyka choroby próchnicowej [23].

\section{Podsumowanie}

Pacjenci poddawani przeszczepieniu komórek krwiotwórczych często cierpią z powodu dolegliwości występujących w jamie ustnej, będących wynikiem terapii choroby podstawowej. Powikłania te mogą zagrażać zdrowiu, a niekiedy nawet życiu pacjentów oraz wpływać negatywnie na proces leczenia. Odpowiednie przygotowanie stomatologiczne przed wdrożeniem postępowania onkologicznego zmniejsza powyższe ryzyko.

Przed rozpoczęciem schematu kondycjonowania należy uświadomić pacjentowi niekorzystny wpływ terapii na stan jamy ustnej oraz poinstruować w zakresie metod zapobiegania i leczenia. Szczegółowe instrukcje higieny jamy ustnej przekazywane pacjentom i ich opiekunom są ważną częścią leczenia stomatologicznego przed HCT. Pacjenci powinni być zmotywowani do rozpoczęcia odpowiedniego schematu higieny na kilka tygodni przed przeszczepem, ponieważ może on złagodzić potencjalne komplikacje w jamie ustnej podczas i po transplantacji. Na etapie przed przeszczepem należy również poinformować pacjentów o konieczności częstych kontroli stomatologicznych, szczególnie w pierwszym roku po zabiegu transplantacji.

Niestety nie wszyscy pacjenci przechodzą specjalistyczne badania stomatologiczne na etapie przed HCT. Przyczyny są złożone.

Nie ma obowiązujących algorytmów postępowania stomatologicznego opartych na wiarygodnych badaniach klinicznych skierowanych do dorosłych pacjentów poddawanych przeszczepowi. Dostępne protokoły oparte na standardach poszczególnych ośrodków transplantacyjnych są czasami sprzeczne i nieprecyzyjne. Różni autorzy różnią się swoimi opiniami, szczególnie jeśli chodzi o definiowanie potencjalnych ognisk infekcji w obrębie układu stomatognatycznego i czy jest obowiązkowe, aby zostały wyeliminowane przed rozpoczęciem chemio-/radioterapii. Niektórzy z nich zdecydowanie opowiadają się za radykalną doustną sanitacją i zalecają usunięcie wszystkich potencjalnych źródeł infekcji. Inni autorzy są jednak za ograniczonym, minimalnie inwazyjnym leczeniem stomatologicznym przed HCT.

Należy zatem dążyć do opracowania i wdrożenia protokołu opieki stomatologicznej, opartego na wiarygodnych badaniach klinicznych oraz do 
włączenia lekarza dentysty do zespołu transplantacyjnego.

\section{Oświadczenia}

Oświadczenie dotyczące konfliktu interesów Autorzy deklarują brak konfliktu interesów w autorstwie oraz publikacji pracy.

\section{Źródła finansowania}

Autorzy deklarują brak źródeł finansowania.

\section{Piśmiennictwo}

[1] Rejestr przeszczepień komórek krwiotwórczych szpiku i krwi obwodowej oraz krwi pępowinowej. Biuletyn Poltransplantu. 2014 maj;1(22).

[2] Copelan EA. Hematopoietic stem cell transplantation. N Engl J Med. 2006;354:1813-1826.

[3] Passweg JR, Baldomero $\mathrm{H}$, et al. Hematopoietic SCT in Europe. 2013: recent trends in the use of alternative donors showing more haploidentical donors but fewer cord blood transplants. Bone Marrow Transplantation. 2015;50:476-482.

[4] Gratwohl A, Baldomero H, et al. Hematopoietic stem cell transplantation: a global perspective. JAMA. 2010;303:1617-1624.

[5] Hong $\mathrm{CH}$, Napeñas JJ, et al. A systematic review of dental disease in patients undergoing cancer therapy. Support Care Cancer. 2010;18(8):1007-21.

[6] Schubert MM, Peterson DE. Oral complications of hematopoietic cell transplantation. W: Appelbaum FR, Forman SJ, Negrin RS, et al. (red.). Thomas' Hematopoietic Cell Transplantation: Stem Cell Transplantation. 4th ed. Oxford, UK: Wiley-Blackwell 2009; s. 1589-1607.

[7] Epstein JB, Thariat J, et al. Oral Complications of Cancer and Cancer Therapy. From Cancer Treatment to Survivorship. Ca Cancer J Clin. 2012;62:400-422.

[8] Elad S, Raber-Durlacher JE, et al. Basic oral care for hematology-oncology patients and hematopoietic stem cell transplantation recipients: a position paper from the joint task force of the Multinational Association of Supportive Care in Cancer/International Society of Oral (MASCC/ISOO) and the European Society for Blood and Marrow Transplantation (EBMT). Support Care Cancer. 2015;23:223-236.

[9] Carter L, Lowis E. Death from overwhelming odontogenic sepsis: a case report. Br Dent J. 2007;203: 241-242.

[10] Epstein JB. Infection prevention in bone marrow transplantation and radiation patients. $\mathrm{NCI}$ Monogr. 1990;9:73-85.

[11] Koulocheris P, Metzger MC, et al. Life-threatening complications associated with acute monocytic leukaemia after dental treatment. Australian Dental Journal. 2009;54:45-48.

[12] Raber-Durlacher JE. Current practices for management of oral mucositis in cancer patients. Support Care Cancer. 1999;7:71-74.

[13] Sonis ST, Woods PD, White BA. Oral complications of cancer therapies. Pretreatment oral assessment. $\mathrm{NCI}$ Monogr. 1990;9:29-32.
[14] Keefe DM, Schubert MM, et al. Updated clinical practice guidelines for the prevention and treatment of mucositis. Cancer. 2007;109:820-31.

[15] Barker GJ. Current practices in the oral management of the patient undergoing chemotherapy or bone marrow transplantation. Support Care Cancer. 1999;7:17-20.

[16] Elad S, Garfunkel AA, et al. Time limitations and the challenge of providing infections - preventing dental care to hematopoietic stem-cell transplantation patients. Support Care Cancer. 2003;11:674-677.

[17] Öhrn, K. Oral Health and Experience of Oral Care among Cancer Patients during Radio- or Chemotherapy. Acta Universitatis Upsaliensis. Comprehensive Summaries of Uppsala Dissertations from the Faculty of Medicine, 2001 Uppsala. ISBN 91-554-4940-9.

[18] Deiana MG. Oral care in children undergoing HSCT. The European Group for Bone and Marrow Transplantation. Paris 2011.

[19] Jędrzejczak WW. Hematologia. Med Tribune. 2011.

[20] Bensinger W, Schubert M, et al. NCCN Task Force Report: Prevention and Management of Mucositis in Cancer Care. JNCCN. 2008;6(1):1-24.

[21] Mierzwińska-Nastalska E, Golecka M. The problem of oral candidiasis among denture wearers after organ transplantation. Nowa Stomatol. 2003;2:97-99.

[22] Sheller B, Williams B. Orthodontic management of patients with haematological malignancies. Am J Orthod Dentofac Orthop. 1996;109:575-580.

[23] National Cancer Institute: Oral Complications of Chemotherapy and Head/Neck Radiation (PDQ ${ }^{\circledR}$ ). Oral and Dental Management Before Cancer Therapy. Health Professional Version. http://www.cancer. gov/cancertopics/pdq/supportivecare/oralcomplications/healthprofessional, 26 January. 2006.

[24] Walsh LJ. Clinical assessment and management of the oral environment in the oncology patient. Australian Dental Journal. 2010;55(1):66-77.

[25] Woo SB, Matin K. Off-site dental evaluation program for prospective bone marrow transplant recipients. JADA. 1997;128:198-193.

[26] Durey K, Patterson H, Gordon K. Dental assessment prior to stem cell transplant: treatment need and barriers to care. Br Dent J. 2009;206:1-8.

[27] Peterson DE. Pretreatment strategies for infection prevention in chemotherapy patients. $\mathrm{NCl}$ Monogr. 1990;9:61-71.

[28] The Royal College of Surgeons of England / The British Society for Disability and Oral Health The Oral Management of Oncology Patients Requiring Radiotherapy, Chemotherapy and/or Bone Marrow Transplantation. Clinical Guidelines Updated. 2012.

[29] Wożakowska-Kapłon B, Filipiak KJ, et al: Contemporary views on prophylaxis of infective endocarditis prior to dental procedures. Czas Stomatol. 2009;62(7):588-596.

[30] Guggenheimer J, Eghtesad B, Stock DJ. Dental management of the (solid) organ transplant patient. Oral Surg Oral Med Oral Pathol Oral Radiol Endod. 2003;95:383-9.

[31] Gürgan CA, Özcan M, Karakuş Ö, Zincircioğlu G, Arat M, Soydan E, Topcuoglu P, Gürman G, Bostancı HS. 
Periodontal status and posttransplantation complications following intensive periodontal treatment in patients underwent allogenic hematopoietic stem cell transplantation conditioned with myeloablative regimen. Int J Dent Hygiene. 2013; 1:84-90.

[32] Scully C, Epstein JB. Oral health care for the cancer patient. Eur J Cancer B Oral Oncol. 1996;32B:281292.

[33] Graber CJ, de Almeida KNF, et al. Dental health and viridans streptococcal bacteraemia in allogeneic hematopoietic stem cell transplant recipients Bone Marrow Transplant. 2001;27:537-542.

[34] Morimoto $Y$, Niwa H, et al. Dental management prior to hematopoietic stem cell transplantation. Spec Care Dentist. 2004;24(6):287-292.

[35] daSilva Santos PS, Coracin FL et al. Impact of oral care prior to HSCT on the severity and clinical outcomes of oral mucositis. Clin Transplant. 2011;25:325-328.

[36] Melkos AB, Massenkeil G, et al. Dental treatment prior to stem cell transplantation and its influence on the posttransplantation outcome. Clin Oral Invest. 2003;7:113-115.

[37] Toljanic JA, Bedard J-F, et al. A prospective pilot study to evaluate a new dental assessment and treatment paradigm for patients scheduled to undergo intensive chemotherapy for cancer. Cancer. 1999;85(8):1843-1848.

[38] Yamagata K, Onizawa K, et al. A prospective study to evaluate a new dental management protocol before hematopoietic stem cell transplantation. Bone Marrow Transplantation. 2006;18:237-242.

[39] Barash A, Peterson DE. Risk factors for ulcerative oral mucositis in cancer patients: unanswered questions. Oral Oncol. 2003;39:91-100.

[40] Carlos-Fabuel L, Gavalda-Esteve C, Sarrion-Perez MG. Dental management in transplant patients. J Clin Exp Dent. 2017;13(1):43-52.
[41] Peters E, Monopoli M, Woo SB, et al. Assessment of the need for treatment of postendodontic asymptomatic periapical radiolucencies in bone marrow transplant recipients. Oral Surg Oral Med Oral Pathol. 1993;76:45-48.

[42] Wilberg P, Hjermstad MJ, et al. Oral health in advanced cancer - a neglected problem? Conference paper of European Journal of Palliative Care, May, 2009.

[43] Bogusławska-Kapała A, Piekarska A, et al. Evaluation of the occurrence of selected symptoms of xerostomia in patients with chronic graft-versus-host-disease (cGvHD). J Stoma. 2014;67(2): 163-182.

[44] Brand HS, Bots CP, Raber-Durlacher J. E. Xerostomia and chronic oral complications among patients treated with haematopoietic stem cell transplantation. Br Dent J. 2009;207:1-4.

Zaakceptowano do edycji: 2018-10-16 Zaakceptowano do publikacji: 2018-12-05

Adres do korespondencji: Agnieszka Bogusławska-Kapała Katedra Stomatologii Zachowawczej Zakład Stomatologii Zintegrowanej Warszawski Uniwersytet Medyczny ul. Miodowa 18, 00-246 Warszawa tel.: 2250220 32, fax: 225022038 e-mail agaka@op.pl 